Article

\title{
Effects of the November 2012 Flood Event on the Mobilization of Hg from the Mount Amiata Mining District to the Sediments of the Paglia River Basin
}

\section{Giulia Pattelli ${ }^{1}$, Valentina Rimondi ${ }^{1}$ *, Marco Benvenuti ${ }^{1}$, Laura Chiarantini ${ }^{1}$, Antonella Colica ${ }^{1}$, Pilario Costagliola ${ }^{1}$, Francesco Di Benedetto ${ }^{1}$, Pierfranco Lattanzi ${ }^{2}$, Mario Paolieri ${ }^{1}$ and Massimo Rinaldi ${ }^{1}$}

${ }^{1}$ Department of Earth Sciences, University of Firenze, via G. La Pira 4, Firenze 50121, Italy; E-Mails: giuliapattelli@ gmail.com (G.P.); m.benvenuti@unifi.it (M.B.); laura.chiarantini@unifi.it (L.C.); antonella.colica@unifi.it (A.C.); pilario.costagliola@unifi.it (P.C.); francesco.dibenedetto@unifi.it (F.B.); mario.paolieri@unifi.it (M.P.); mrinaldi@dicea.unifi.it (M.R.)

${ }^{2}$ Department of Chemical and Geological Sciences, University of Cagliari, via Trentino 51, Cagliari 09127, Italy; E-Mail: lattanzp@unica.it

* Author to whom correspondence should be addressed; E-Mail: valentina.rimondi@unifi.it; Tel: +39-055-2757507; Fax: +39-055-284571.

Received: 28 February 2014; in revised form: 1 April 2014 /Accepted: 2 April 2014 / Published: 9 April 2014

\begin{abstract}
The Mount Amiata mining district (southern Tuscany, Italy) was, for decades, one of the world's largest mercury $(\mathrm{Hg})$ producing regions, where mining activity lasted until the 1980s. The Paglia River drains the eastern part of the district and is also the main western tributary of the Tiber River. Recent studies show that, still today, high total $\mathrm{Hg}$ contents severely affect the downstream ecosystems of these rivers. In November 2012, a major flood event occurred in the Paglia River basin, which drastically changed the river morphology and, possibly, the $\mathrm{Hg}$ concentrations. In the present work, stream sediment was sampled before and after the flood to evaluate possible changes in sediment total $\mathrm{Hg}$ concentrations as a consequence of this event. The comparison between pre- and post-flood $\mathrm{Hg}$ concentrations shows that $\mathrm{Hg}$ content increased up to an order of magnitude after the flood, suggesting that this event triggered $\mathrm{Hg}$ mobilization in the basin rather than its dilution.
\end{abstract}

Keywords: mercury; mining; Mount Amiata; sediment; flood; dam 


\section{Introduction}

In recent decades, human civilization and a concomitant increase in industrial activity have gradually redistributed many toxic metals from the Earth's crust to the environment, increasing the possibility of human exposure. Mercury has accumulated in soils, where it is present in a large variety of chemical forms, bound to the finest soil fractions [1].

Mercury does not serve any known biological benefits or functions, and most of its compounds are toxic, even at low doses [2].

Globally, approximately one million metric tons mercury $(\mathrm{Hg})$ have been extracted from various ore bodies in the world [3], most notably in the Mediterranean region [4-7], which hosts about $65 \%$ of the world's cinnabar ( $\mathrm{HgS})$ deposits [8]. Recent studies documented high mercury concentrations in Mediterranean fish, likely due to this geogenic (and anthropogenic) anomaly [4].

The Mount Amiata mining district (MAMD), located in southern Tuscany (Italy), belongs to the circum-Mediterranean $\mathrm{Hg}$ belt (Figure 1) and covers $400 \mathrm{~km}^{2}$ [9].

About 102,000 metric tons of $\mathrm{Hg}$ were produced from the 1860s to 1980 in this region [9], ranking it as the fourth largest $\mathrm{Hg}$ producing district worldwide. The Paglia River draining this area is one of the main tributaries of the Tiber River (the third longest river in Italy), which discharges into the Mediterranean Sea. The Tiber River may then be considered as one of the main contributors to the total Hg budget of the Mediterranean Sea.

Because the process of $\mathrm{Hg}$ recovery involves roasting (calcination), the mine waste generated is referred to mine waste calcine, or simply calcine. As the retorting of $\mathrm{Hg}$ ore mineral (generally cinnabar) is an inefficient process, waste calcines found at most $\mathrm{Hg}$ mines contain unconverted cinnabar, $\mathrm{Hg}(0)$ and ionic $\mathrm{Hg}$ compounds formed during processing [10,11]. Leaching and erosion of mine-waste result in anomalously high $\mathrm{Hg}$ concentrations in stream sediment and water [12-15], even decades after the end of mining [13,16-19]. The presence of $\mathrm{Hg}$ in rivers results in a contamination reaching coastal areas and marine ecosystems hundreds of kilometers away from the primary source [13,20].

The Paglia River has a key role in the transport of $\mathrm{Hg}$, because it drains the south-eastern part of the MAMD, collecting water from different mines located at the head of its tributaries (Figure 2). This river has a torrential regime, especially in the upper mountain part [21], and in association with intense rainy events, flash floods are often documented [22]. Storm events are known to have a major role in the remobilization of river bank sediment, providing large amounts of $\mathrm{Hg}$ into ecosystems in the surroundings of $\mathrm{Hg}$ mines [23,24]. Under these conditions, enormous quantities of contaminated particulate are mobilized as a result of the high runoff, increasing the capacity of the stream to erode contaminated banks and sediment transport.

In a recent study carried out on fish, soils, stream water and sediment, Rimondi et al. [16] showed that, although more than 30 years have passed since the mining activity came to a complete halt, Hg-rich processing residues and abandoned mine structures still constitute an environmental pollution problem.

A further study [25] documented the long-distance transport of $\mathrm{Hg}$ on the Tiber River, testifying long-range transport downstream from the MAMD (Figure 2).

In November 2012, a major flood event occurred in the Paglia and Tiber river catchments, causing mobilization of huge masses of sediment and changes in river morphology (Figure 3). Data from a 
pluviometric station in this area (Piancastagnaio) indicate an intense precipitation of $328 \mathrm{~mm}$ in $48 \mathrm{~h}$, and 350 million $\mathrm{m}^{3}$ water were estimated to have precipitated in the Paglia River basin following this event [26].

In the present work, we compare analyses of stream sediment of the Paglia and Tiber rivers before (September 2012; Figure 2) and after (March-May 2013; Figure 4) the flood event, which occurred in November 2012, to assess its effects on total Hg contents.

Figure 1. Distribution of mercury (Hg) global belts. The circum-Mediterranean $\mathrm{Hg}$ belt (red area) and the most important mining districts for $\mathrm{Hg}$ production are reported.

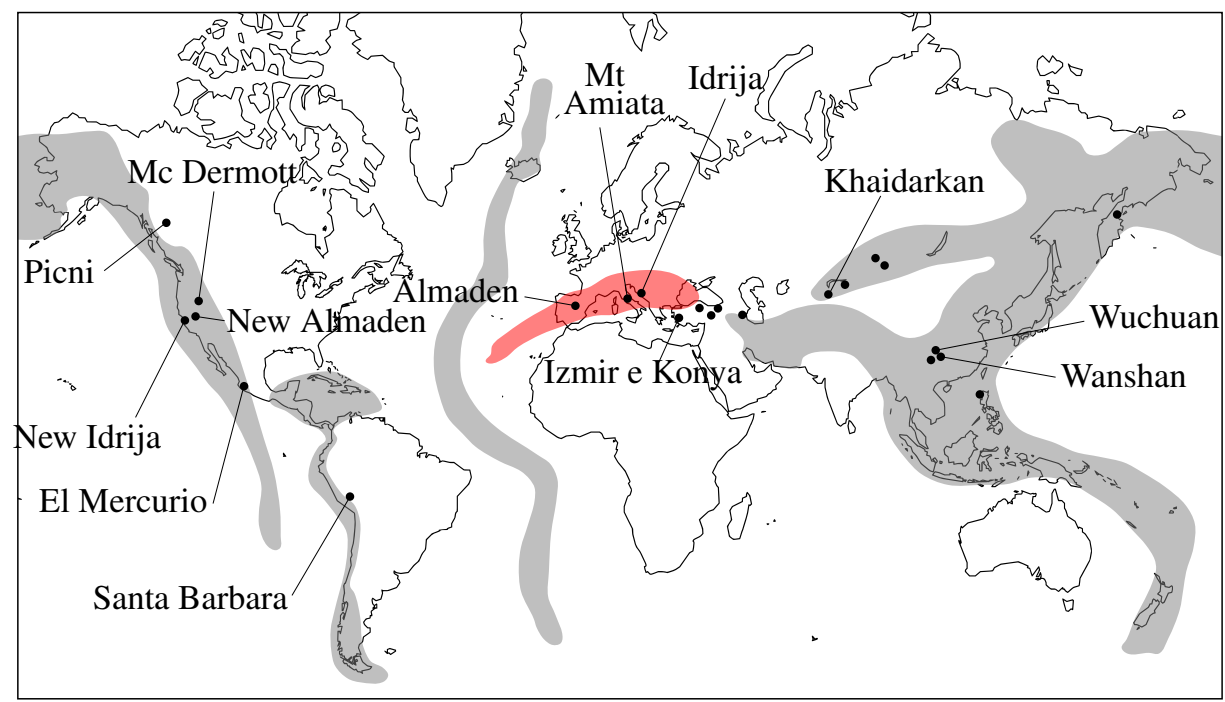

Figure 2. Localization of the study area and sampling sites of the September 2012, campaign (pre-flood). MAMD stands for the Mount Amiata mining district.

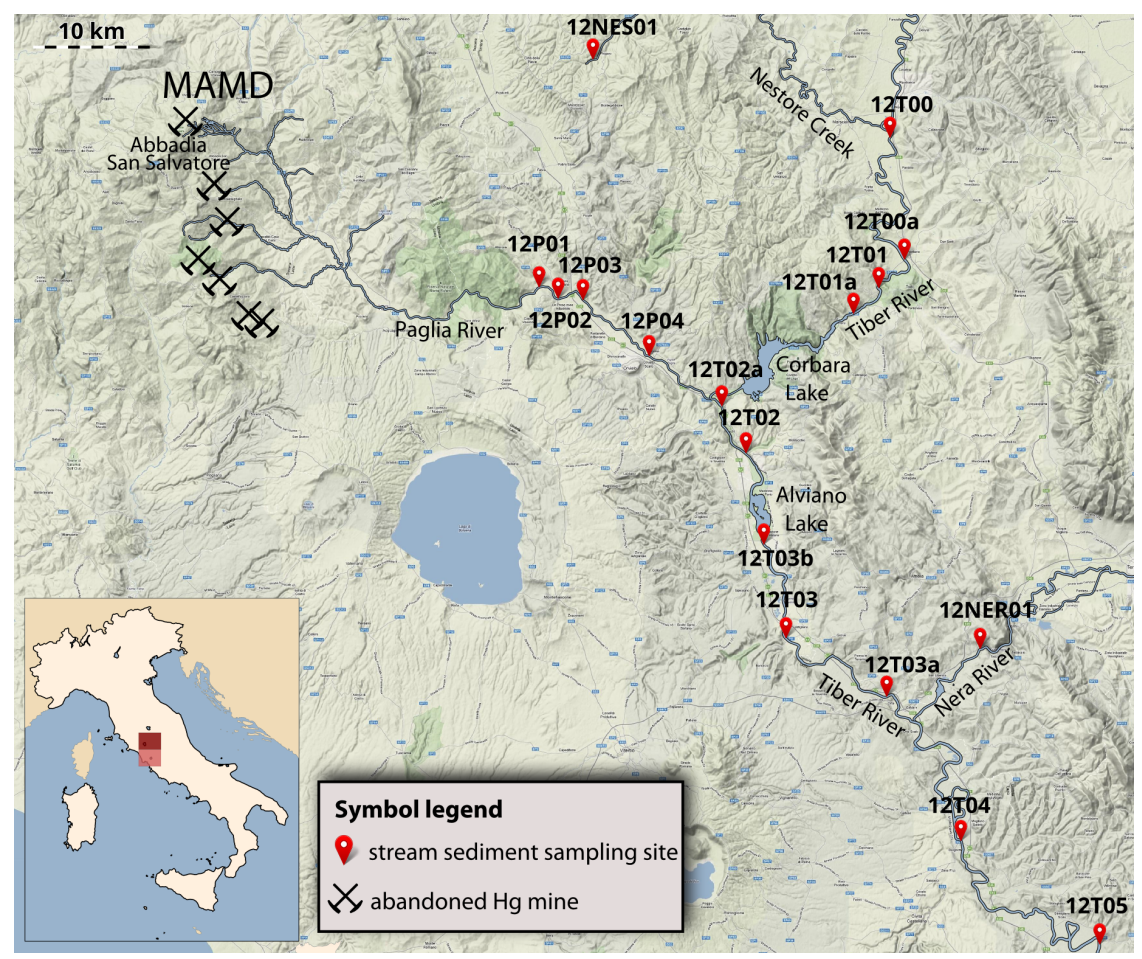


Figure 3. Comparison of the channel morphology of the Paglia River before and after the flood event of November 2012. (a) represents the pre-flood state (September 2012), while (b) shows the post-flood set-up (March-May 2013). Pictures refer to the PC01 sampling point (collocation in Figure 4). The trees indicated by the red arrows may be employed as reference spatial points.

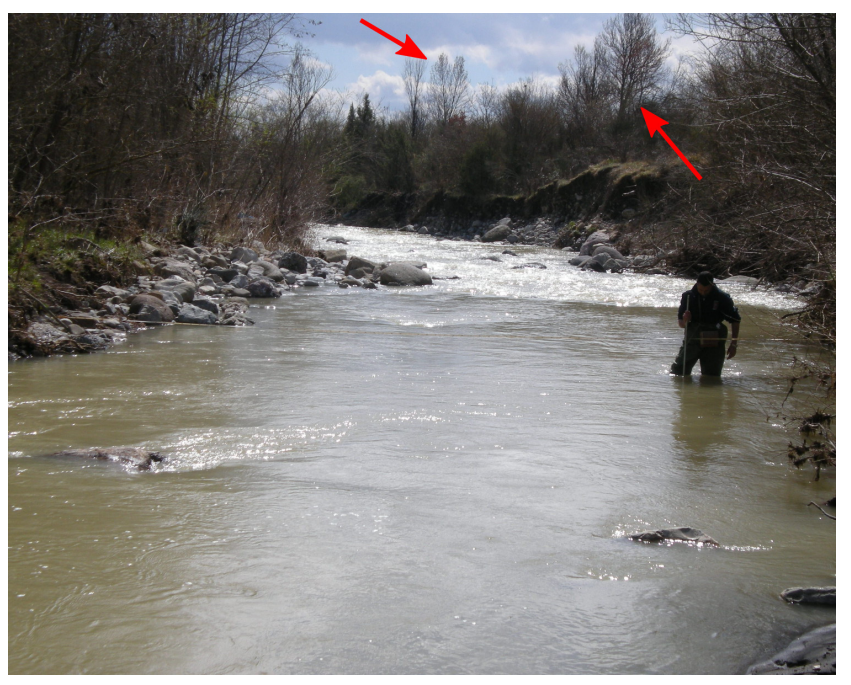

(a)

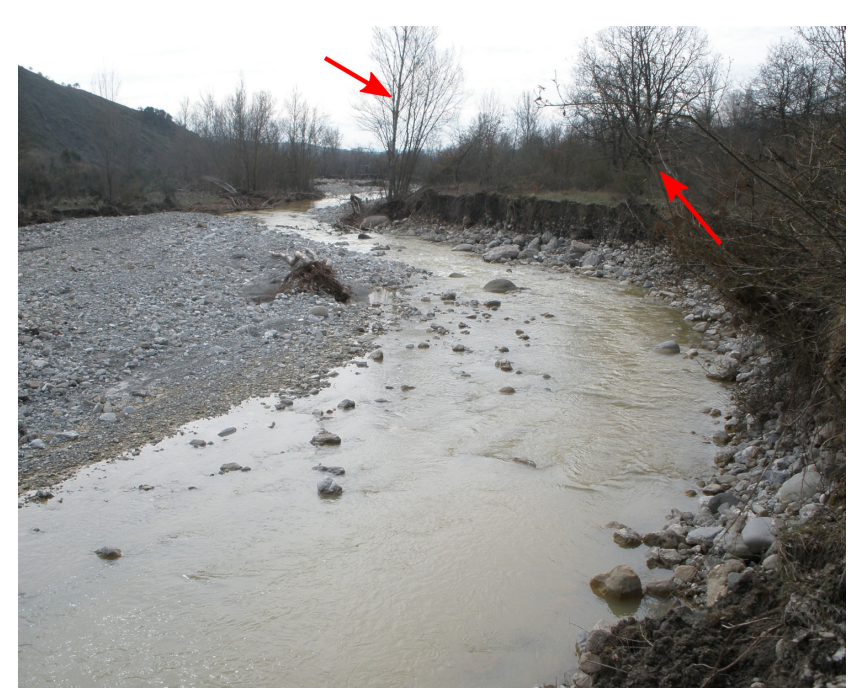

(b)

Study Area

In southern Tuscany, a wide $\mathrm{Hg}$ metallogenic province has clustered around the volcano-geothermal area of Mount Amiata, as a result of the post-collisional events of the Northern Apennines orogenesis [34]. Although mining exploitation in this district started with the Etruscans (about 800 BC) [27-29], large-scale mining activity in this region began only in the late 19th century.

The main mining center was in Abbadia San Salvatore, which was the last mine to close in this district in 1982, after a total production of more than 50,000 metric tons $\mathrm{Hg}$ [30]. The $\mathrm{Hg}$ content in Mount Amiata ore ranges between 0.6 and $2 \mathrm{wt} \%$. The primary ore assemblage is essentially cinnabar [31]. Non-economic minerals found in association with cinnabar are marcasite $\left(\mathrm{FeS}_{2}\right)$, pyrite $\left(\mathrm{FeS}_{2}\right)$, stibnite $\left(\mathrm{Sb}_{2} \mathrm{~S}_{3}\right)$ and rare arsenical sulfides (realgar, $\mathrm{As}_{4} \mathrm{~S}_{4}$, and orpiment, $\left.\mathrm{As}_{2} \mathrm{~S}_{3}\right)$ [32,33]. The typical gangue mineral is calcite $\left(\mathrm{CaCO}_{3}\right)$ and, rarely, celestite $\left(\mathrm{SrSO}_{4}\right)$, gypsum $\left(\mathrm{CaSO}_{4} \cdot 2 \mathrm{H}_{2} \mathrm{O}\right)$, native sulfur and hydrocarbons [34,35].

A remediation project is presently being carried on at the mine site of Abbadia San Salvatore by the local municipality. Although the runoff from contaminated waste has been reduced, tailings deposits are still present along the river banks.

In the present work, the study area includes the western part of the Paglia River (which has a drainage basin of about $1330 \mathrm{~km}^{2}$ ) and a portion of the Tiber River catchment together with some of its tributaries (Figure 2). The Paglia River drains the eastern part of the MAMD, and after about $40 \mathrm{~km}$, it flows into the Tiber River (Figure 2).

From a geological point of view, the Tiber River Valley is an extensional basin developed since the late Early Pliocene, characterized by a wide outcropping of sedimentary and volcanic successions [36]. 
The Tiber River basin is highly urbanized with a population exceeding 4,000,000 residents (70\% of which live in the urban area of Rome); moreover, the basin area is relevant for agriculture, ranching and industrial activities. Two dams have been built along the Tiber River in the 1960s, when Hg mining and production in the MAMD were still active, forming the reservoirs of Lake Corbara and Lake Alviano (Figure 2).

In spite of its importance, until recently, no investigations have been carried out in the Tiber River basin to determine the impact of $\mathrm{Hg}$ transported by the Paglia River and to quantify the amount of $\mathrm{Hg}$ that is consequently delivered to the Mediterranean Sea.

Figure 4. Representation of the sampling sites of the March-May 2013, campaigns (post-flood). (b) is an enlargement of the red square in (a).

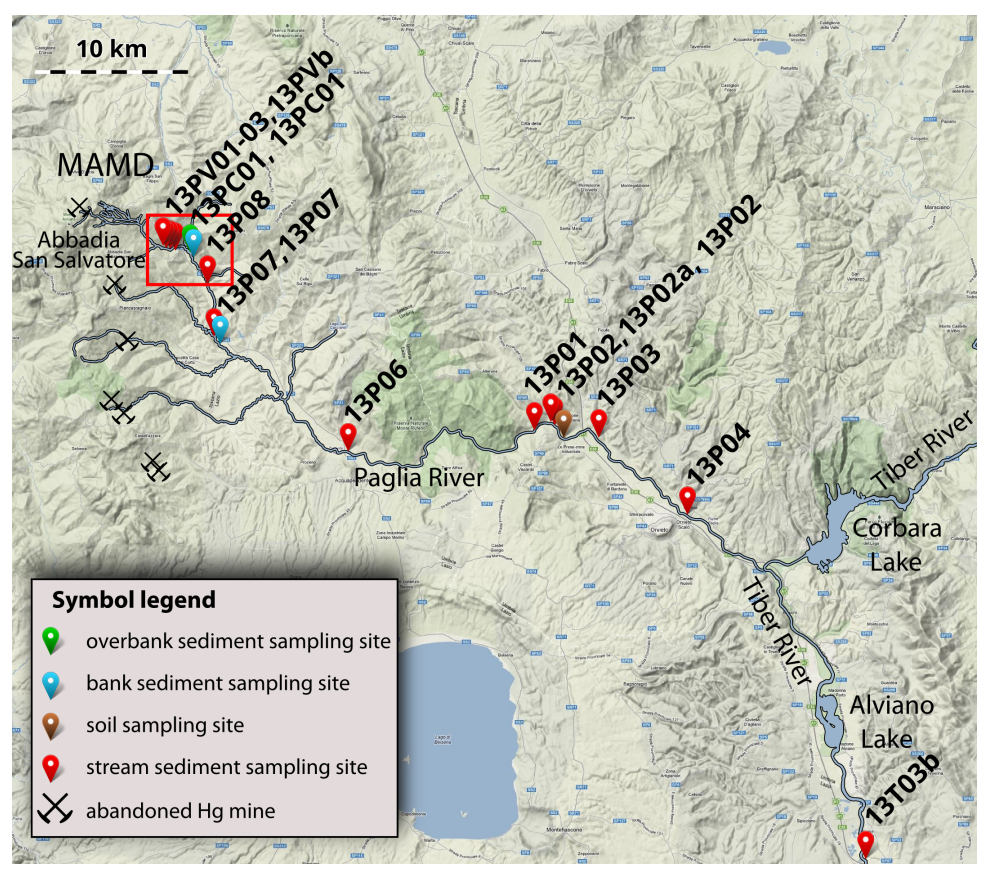

(a)

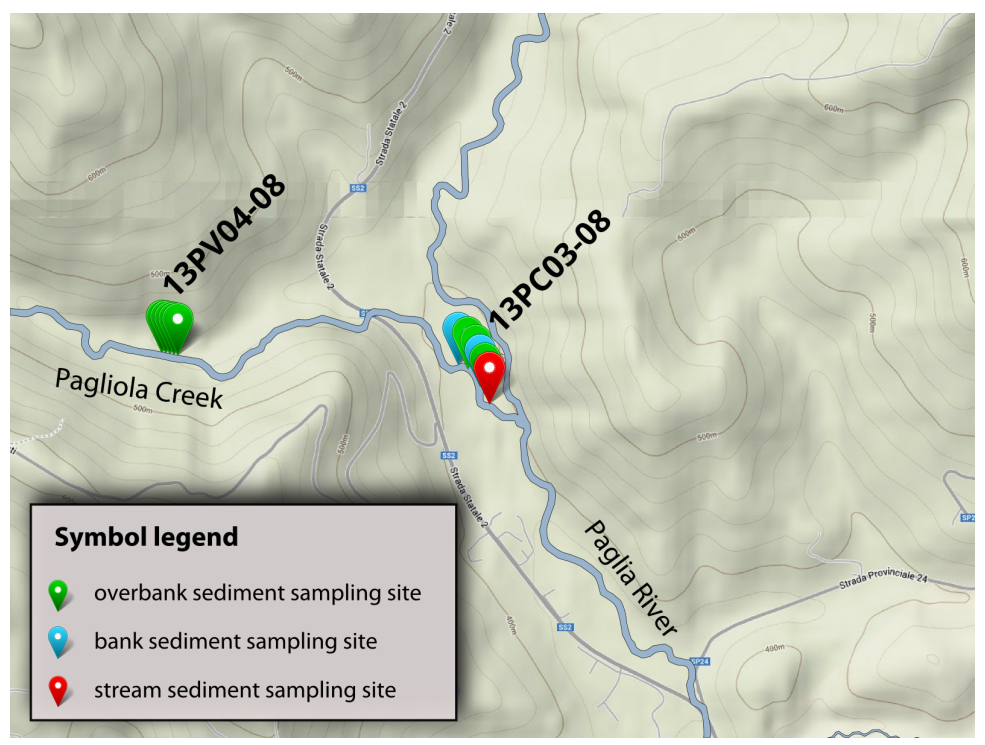

(b) 


\section{Experimental Section}

\subsection{Sample Collection}

In this study, two time-distinct sampling campaigns were performed, i.e., before and after the major flood occurred in the Paglia River in November 2012, which has greatly affected the river morphology (cf. Figure 3).

The pre-flood campaign (Figure 2) was carried out in September 2012, and consisted of 17 stream sediment samples. Sampling sites coincide with some of Gray's et al. study [25], collected at the same time.

The post-flood campaign was conducted in March-May 2013. Twenty-nine samples of stream sediment, topsoil, bank and overbank sediment were collected in the Paglia and Tiber rivers downstream of the mining site (Figure 4). Overbank sediment refers to the one deposited on the floodplain overtopping the river banks. Sampling focused on the Paglia River basin, extending from a site (PV) located $5 \mathrm{~km}$ downstream of the MAMD, down to Orvieto (P04). A single sample (13T03) was taken along the Tiber River, $23 \mathrm{~km}$ downstream of the confluence with the Paglia River and downstream of the Alviano dam (Figure 4a).

Nera River and Nestore Creek have been chosen as the regional baseline for Hg concentrations, since they are tributaries of the Tiber River located far away from MAMD (Figure 2).

All sediment samples were collected using a plastic scoop; to avoid contamination, sampling was started from sites distal from the $\mathrm{Hg}$ district, where the lowest $\mathrm{Hg}$ concentration samples were expected. Samples were taken in the top $2 \mathrm{~cm}$ and transferred in new plastic bags. Stream sediment was collected on the shoreline next to the river, where accumulation of fine material was observed. A sample was made of three subsamples recovered in different locations of the same sampling site.

In the following, the suffix of the sample ID, 12 or 13, refers to the year of sampling, 2012 and 2013, and it is then distinctive of pre-flood and post-flood campaigns.

\subsection{Sample Analysis}

Stream, bank and overbank sediment and soils were air-dried, sieved at $200 \mu \mathrm{m}$ and ground before analysis. The concentration of $\mathrm{Hg}$ was determined using aqua-regia microwave digestion (20 min, $175^{\circ} \mathrm{C}$ ). The supernatant solution was separated from the remaining solid by centrifugation for $30 \mathrm{~min}$ at $4000 \mathrm{rpm}$. Dissolved Hg concentrations were determined by flow injection cold vapor atomic absorption spectroscopy (FI-CVAAS) with a Perkin Elmer FIAS 100 (Waltham, MA, USA) at Department of Earth Sciences, University of Firenze.

The precision and accuracy for $\mathrm{Hg}$ analysis were established using a blank method and standard reference materials (SRMs): 2710 (certified value: $32.6 \mu \mathrm{g} / \mathrm{g}$ ) and 2711 (certified value: $6.25 \mu \mathrm{g} / \mathrm{g}$ ). The relative percent differences for the SRMs were $\leq 4 \%$. Method blanks and SRMs were run as 1 per every 10 samples. Method blanks contained $\mathrm{Hg}$ close or below the lower limit of determination $(1 \mathrm{ng} / \mathrm{g})$. As an additional control of analytical accuracy, 20 samples were analyzed by ACME International laboratories (Vancouver, BC, Canada): with the exception of 4 samples (12NES01(stream sediment (ss)), 12T01(ss), 13T03(ss), 12T05(ss)), differences with our values were, on average, about $25 \%$. These four samples all 
have low $\mathrm{Hg}$ concentrations (Tables 1 and 2) and did not influence the overall data interpretation. For internal consistency, in Tables 1 and 2 we report the analytical values determined by our laboratory.

\section{Results and Discussion}

The concentration of $\mathrm{Hg}$ in stream samples collected from the Paglia and Tiber rivers in 2012 pre-flood and in the 2013 post-flood campaigns is reported in Tables 1 and 2, respectively. In 2012, $\mathrm{Hg}$ in stream sediment varies from 0.1 to $7.5 \mu \mathrm{g} / \mathrm{g}$, average $1.2 \mu \mathrm{g} / \mathrm{g}$, a range comparable to that reported by Gray et al. [25] for the same sampling sites. Stream sediment with the lowest $\mathrm{Hg}$ concentrations $(0.1$ to $0.5 \mu \mathrm{g} / \mathrm{g}$ ) are those collected from the eastern section of the Tiber River (upstream of the confluence with the Paglia River), which does not receive runoff from the $\mathrm{Hg}$ mines of the MAMD (Figure 2). Along the Paglia River, stream sediment $\mathrm{Hg}$ concentration ranges from 0.9 to $7.5 \mu \mathrm{g} / \mathrm{g}$, with an average of $3 \mu \mathrm{g} / \mathrm{g}$.

Table 1. Total mercury concentrations for stream sediment (ss) collected along Paglia and Tiber rivers during the September 2012, campaign. Samples are ordered from the nearest to the farthest from the Mount Amiata mining district (MAMD).

\begin{tabular}{|c|c|c|c|}
\hline Sample & km from the MAMD & River & Total Hg $(\mu \mathrm{g} / \mathrm{g})$ \\
\hline \multicolumn{4}{|c|}{ Downstream of the mine } \\
\hline $12 \mathrm{P} 01(\mathrm{ss})$ & 33 & Paglia & 1.7 \\
\hline $12 \mathrm{P} 02(\mathrm{ss})$ & 35 & Paglia & 7.5 \\
\hline 12P03(ss) & 38 & Paglia & 1.8 \\
\hline $12 \mathrm{P} 04(\mathrm{ss})$ & 46 & Paglia & 0.9 \\
\hline \multicolumn{4}{|c|}{ Downstream of the confluence } \\
\hline $12 \mathrm{~T} 02 \mathrm{a}(\mathrm{ss})$ & 1 & Tiber & 2.5 \\
\hline $12 \mathrm{~T} 02(\mathrm{ss})$ & 6 & Tiber & 1.3 \\
\hline $12 \mathrm{~T} 03 \mathrm{~b}(\mathrm{ss})$ & 13 & Tiber & 0.7 \\
\hline $12 \mathrm{~T} 03(\mathrm{ss})$ & 23 & Tiber & 0.7 \\
\hline $12 \mathrm{~T} 03 \mathrm{a}(\mathrm{ss})$ & 35 & Tiber & 0.5 \\
\hline $12 \mathrm{~T} 04(\mathrm{ss})$ & 60 & Tiber & 0.4 \\
\hline $12 \mathrm{~T} 05(\mathrm{ss})$ & 90 & Tiber & 1.0 \\
\hline \multicolumn{4}{|c|}{ Upstream of the confluence } \\
\hline $12 \mathrm{~T} 00(\mathrm{ss})$ & -15 & Tiber & 0.1 \\
\hline $12 \mathrm{~T} 00 \mathrm{a}(\mathrm{ss})$ & -20 & Tiber & 0.4 \\
\hline $12 \mathrm{~T} 01(\mathrm{ss})$ & -25 & Tiber & 0.5 \\
\hline $12 \mathrm{~T} 01 \mathrm{a}(\mathrm{ss})$ & -45 & Tiber & 0.1 \\
\hline \multicolumn{4}{|l|}{ Baseline } \\
\hline 12NES01(ss) & - & Nestore & 0.3 \\
\hline 12NER01(ss) & - & Nera & 0.2 \\
\hline
\end{tabular}


Table 2. Total mercury concentrations for stream sediment (ss), soil (so), bank (b) and overbank (ob) collected along Paglia River after the November 2012, flood event.

\begin{tabular}{llc}
\hline Sample & River & Total Hg $(\boldsymbol{\mu g} / \mathbf{g})$ \\
\hline 13PV01(ss) & Pagliola & 53 \\
13PV02(ss) & Pagliola & 20 \\
13PV03(ss) & Pagliola & 5 \\
13PV04(ob) & Pagliola & 225 \\
13PV05(ob) & Pagliola & 67 \\
13PV06(ob) & Pagliola & 297 \\
13PV07(ob) & Pagliola & 20 \\
13PV08(ob) & Pagliola & 27 \\
13PVb(ss) & Pagliola & 19 \\
13PC01(b) & Paglia & 905 \\
13PC01(ob) & Paglia & 2 \\
13PC02(ss) & Paglia & 3 \\
13PC03(b) & Paglia & 300 \\
13PC04(ob) & Paglia & 2 \\
13PC05(ob) & Paglia & 63 \\
13PC06(b) & Paglia & 125 \\
13PC07(ob) & Paglia & 115 \\
13PC08(ss) & Paglia & 105 \\
13P01(ss) & Paglia & 2 \\
13P02(so) & Paglia & 2 \\
13P02(ss) & Paglia & 13 \\
13P02a(ss) & Paglia & 4 \\
13P03(ss) & Paglia & 3 \\
13P04(ss) & Paglia & 0.05 \\
13P06(ss) & Paglia & 16 \\
13P07(ss) & Paglia & 40 \\
13P07(b) & Paglia & 17 \\
13P08(ss) & Paglia & 10 \\
13T03(ss) & Tiber & 3 \\
\hline & & \\
\hline
\end{tabular}

Data collected during the 2013 survey exhibit a $\mathrm{Hg}$ range between 0.05 and $105 \mu \mathrm{g} / \mathrm{g}$, with an average of $18.6 \mu \mathrm{g} / \mathrm{g}$ (Table 2). Almost all $\mathrm{Hg}$ concentrations in the post-flood stream sediment samples are apparently increased, if compared to the pre-flood data (Figure 5) (to increase the comparison, data from the study of Rimondi et al. [16] conducted in 2010 were also evaluated). Accordingly, statistical analysis performed applying the $\mathrm{F}$ test indicates that differences between the two datasets shown in Figure 5 are statistically significant, although the low number of samples may impair these results.

In particular, samples P07 and P08 are increased by an order of magnitude. Accordingly, even in the stream sediment collected along the Tiber River at the site T03 in 2013, the Hg content was four times bigger than the value obtained in 2012 . 
Figure 5. Semi-logarithmic plot showing the comparison between total $\mathrm{Hg}$ concentrations before and after the November 2012, flood event. Light grey columns represent the concentration before the flood (from the 2010 and 2012 campaigns), while the dark grey ones indicate the post flood data (2013). 2010 data are available in the literature [16] and refer to P07, P08, PC and PV sampling sites.

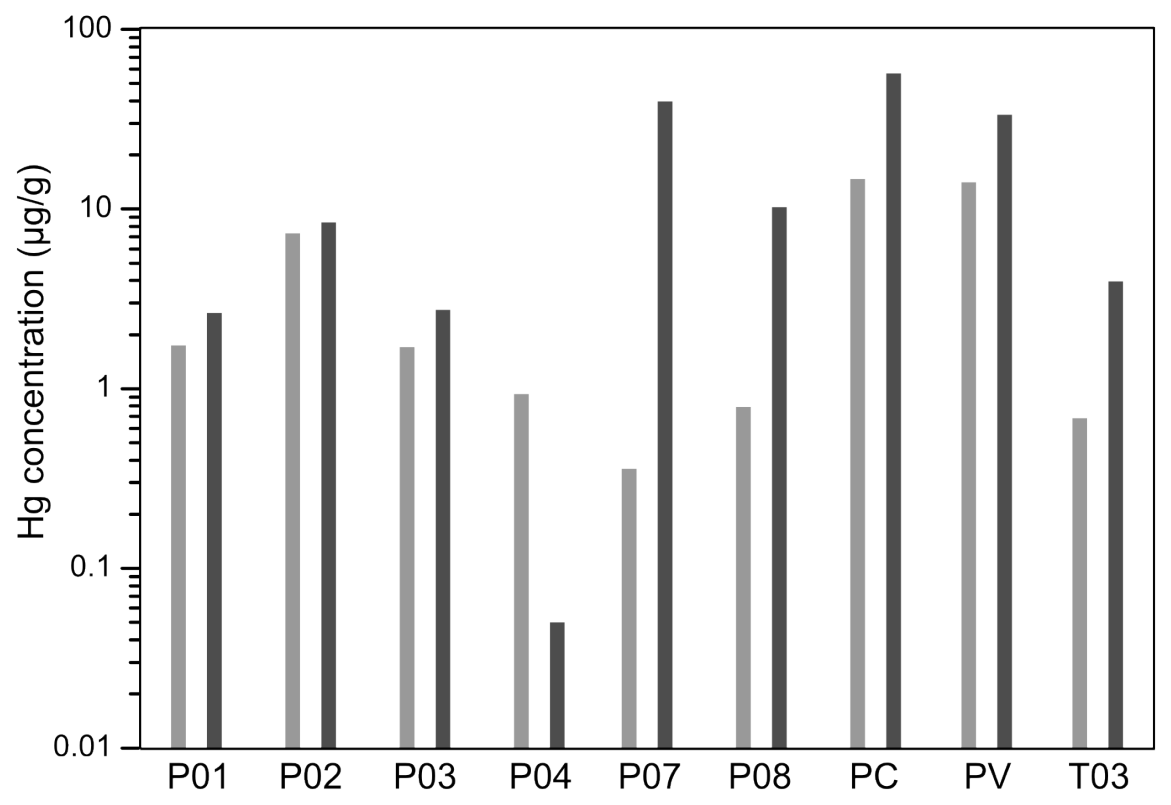

Mercury in bank sediment collected during 2013 has an average of $337 \mu \mathrm{g} / \mathrm{g}$ and showed a peak of $905 \mu \mathrm{g} / \mathrm{g}$ at the PC sampling site (Figure 4a), located $5 \mathrm{~km}$ downstream of the mine of Abbadia San Salvatore. Such concentrations are two orders of magnitude higher than those observed in stream sediment samples collected in the same period (March-May 2013).

MAMD clearly influences sediment $\mathrm{Hg}$ concentration in both the Paglia and Tiber Rivers. Considering the complete stream sediment dataset, more than $45 \%$ of the samples exceeded both the Italian industrial soil sediment limit for $\mathrm{Hg}$ of $5 \mu \mathrm{g} / \mathrm{g}$ [37] and the probable effect concentration of $1.06 \mu \mathrm{g} / \mathrm{g}$ (PEC, concentration above which harmful effects are likely to be observed in sediment dwelling organisms [38]) (Figure 6), particularly during 2013. This percentage increases up to 66\% if samples collected along the Paglia River are exclusively considered, suggesting that $\mathrm{Hg}$ could be easily delivered to the river, especially during flood events, thus potentially influencing the whole river ecosystem. In particular, river banks show extremely elevated $\mathrm{Hg}$ contents (approaching $1000 \mu \mathrm{g} / \mathrm{g}$ ), greatly exceeding both the Italian and the U.S. Environmental Protection Agency (EPA) limits for industrial soils (five and $310 \mu \mathrm{g} / \mathrm{g}$, respectively) (Figure 6), and thus, they represent a potential source for $\mathrm{Hg}$ mobilization through erosion. The case of MAMD and the associated Paglia River is not an exception. For example, more that $2.000 \mathrm{Hg}$ metric tons are estimated to be presently stored in the alluvial sediment of Idrijca River (Idrija mine, Slovenia), suggesting that the erosion of these deposits may greatly increase the remobilization and transport of $\mathrm{Hg}$ to the Adriatic Sea long after mining has ceased [39]. 
Figure 6. The semi-logarithmic scale graph shows the 2012 and 2013 total $\mathrm{Hg}$ concentrations in all samples compared with the probable effect concentration (PEC), Italian and U.S. Environmental Protection Agency (EPA) limits for industrial soils. Red triangles represent soils, bank and overbank sediment collected along the Paglia River; green circles and blue squares represent stream sediment total $\mathrm{Hg}$ concentrations of the Paglia and Tiber rivers, respectively, while orange triangles symbolize stream sediment collected along Nestore Creek and Nera River. The latter two sites are considered regional baseline sites, located upstream of the known mining impact. The analytical error is below $5 \%$.

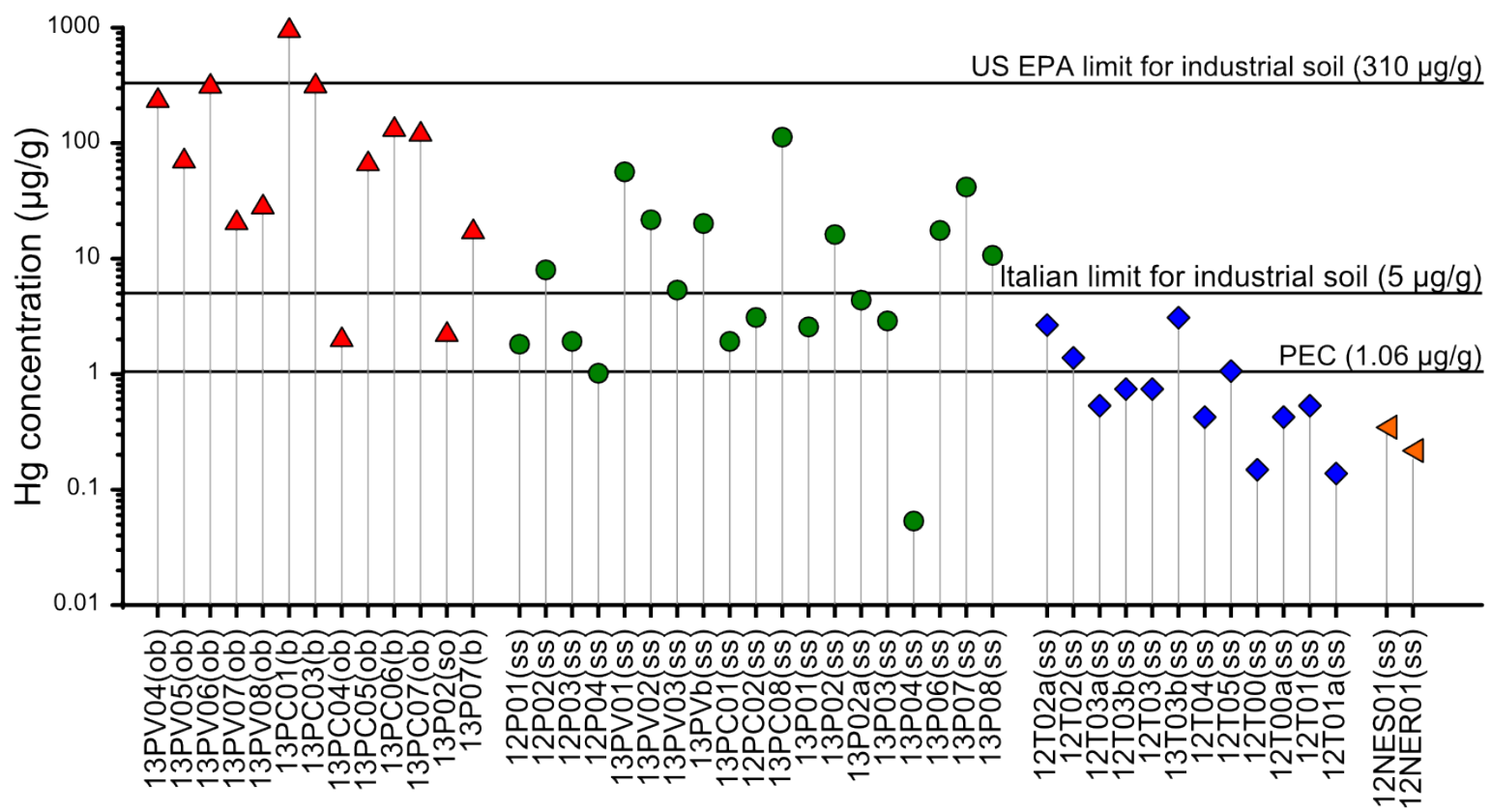

The comparison of $\mathrm{Hg}$ concentrations in stream sediment before and after the flood of November 2012, indicates that during this event, the Paglia River ecosystem did not experience a dilution, due to the admission of sediment with relatively low $\mathrm{Hg}$ concentrations, but, on the contrary, the $\mathrm{Hg}$ concentration underwent an appreciable increase. Because river banks of the Paglia River turned out to be highly enriched in $\mathrm{Hg}$, such a $\mathrm{Hg}$ increase is likely related to the erosion and transport of the $\mathrm{Hg}$ stored in these areas of the Paglia River. In this way, flood deposits in the Mount Amiata area are, depending on the environmental conditions, both a source and a sink of the mass exchange between river and floodplain areas. Hence, river banks and overbank deposits reflect the present quality of the fluvial system and, to some extent, they could determine its future quality.

These results demonstrate that stream sediment compositions are highly time-dependent in streams, especially where pollutants are mainly partitioned in the particulate matter (cf. [40]). Accordingly, the measurement of contaminant mass loadings, although being one of the most reliable tool in monitoring watercourse quality, provides only a snapshot of their actual distribution ( $c f$. [41]).

Due to the torrential regime and, particularly, in association with intense rainy events, flash floods and associated sliding-like mud and debris flows are very common along the Paglia River catchment [22]. According to some global climate change scenarios [42], the frequency of the so-called extreme events might increase in the future. Such events, coupled with the severe denudation processes that characterize this area (Mio-Pliocene deposits, which extensively crop out along the Paglia River, represent erodible 
lithologies [43]), will lead to the remobilization of river bank sediment. The importance of the episodic transport of $\mathrm{Hg}$ following storm events is stressed in various mining districts [44,45]. Under water floods, enormous quantities of $\mathrm{Hg}$-contaminated suspended particulate matter are mobilized as a result of higher runoff, the increased capacity for the stream to erode contaminated soils and transport sediment [46], resulting in up to an 80-fold increase of $\mathrm{Hg}$ transport [46]. Particularly, eight days of the flood event in the Isonzo River (Idrija mine) were sufficient to mobilize up to three times the amount of $\mathrm{Hg}$ transported in a whole year [47].

As documented by Gray et al. [25] and confirmed by this study, the concentration of Hg drops almost to background levels immediately downstream of the Alviano dam (Figure 7), indicating that this dam acts as a physical barrier for $\mathrm{Hg}$ transport, promoting the deposition of $\mathrm{Hg}$-contaminated particulate. Accordingly, $\mathrm{Hg}$ contents of fish tissues show a remarkable decrease along with distance from MAMD, suggesting that bioavailable $\mathrm{Hg}$ (mainly methyl-Hg) follows a similar trend.

This effect on $\mathrm{Hg}$ transport is well documented in the literature [48,49]. Three dams located along the Idrijca-Isonzo River system cause a drastic decrease of sediment, together with a considerable decrement of Hg concentrations [48].

It has been estimated that the annual sediment load in Alviano Lake is about $850,000 \mathrm{~m}^{3} /$ year. During intense hydrological events, as those affecting the Paglia River catchment, the Alviano dam can be opened in order to release sediment downstream. This operation could potentially represent a hazard for the Tiber River ecosystem, since Hg-rich sediment could be transported to the river mouth, resulting in $\mathrm{Hg}$ contamination up to coastal areas. Hence, even if this dam seems to work as an environmental filter, it halts $\mathrm{Hg}$ transport only temporarily and does not solve the pollution problem.

Figure 7. Total mercury concentrations in the Tiber River stream sediment samples collected in the 2012 campaign. Dashed lines represent the confluence point with the Paglia River and Alviano dam.

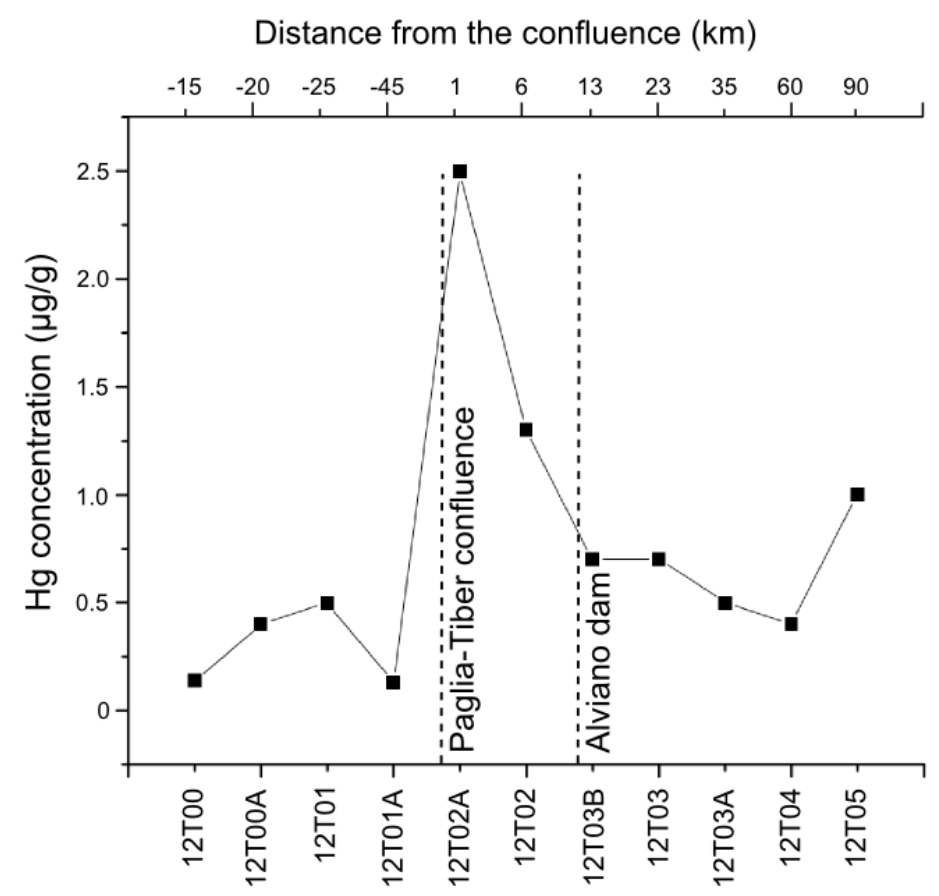




\section{Conclusions}

As recently documented by previous studies in this area, the data here presented confirm that, after three decades from the end of mining activity in the Mount Amiata district, a pervasive $\mathrm{Hg}$ diffusion is still present in the Paglia River and extends to the Tiber ecosystem, becoming a contamination of regional importance.

The most elevated $\mathrm{Hg}$ concentrations refer to bank and overbank sediment along the Paglia River, where $\mathrm{Hg}$ reached $905 \mu \mathrm{g} / \mathrm{g}$.

Bank erosion and remobilization function as a source of $\mathrm{Hg}$ during floods, which are very common and well-documented in the Paglia River. During these events, water is able to remobilize high volumes of sediment, and a significant amount of $\mathrm{Hg}$ enters the river water course, representing a hazard for the ecosystems of both the Paglia and Tiber rivers. The recent trends of climate change might increase the frequency of extreme events, including extraordinary rainfalls and consequent floods. Dams along the Tiber River, like that of Alviano, represent a physical barrier for Hg-rich sediment, which limits, at least temporarily, the $\mathrm{Hg}$ input in the lower part of the basin. However, such a barrier is limited in time, as extraordinary opening of the dam would result in the release of $\mathrm{Hg}$-rich sediment in the downstream environment.

Future studies are therefore needed in order to plan adequate monitoring and remediation strategies, given the potential influence of the Paglia-Tiber river system on the $\mathrm{Hg}$ geochemistry of the Mediterranean Sea. Specifically, the ongoing reclamation at the Abbadia San Salvatore mine should reduce runoff from the mine area to the Paglia River. The actual effect of this reclamation should be quantitatively assessed by new studies of $\mathrm{Hg}$ transport in the Paglia and Tiber basins. This represents an unavoidable prerequisite for any program of sediment quality management in this area (cf. [50]).

\section{Acknowledgments}

This study was financially supported by Ente the Cassa di Risparmio di Firenze and funds provided by the Italian Ministery of University and Research (MIUR PRIN 2010-2011) (grant to P.C.). Daniele Rappuoli and Marcello Niccolini (Municipality of Abbadia San Salvatore) are gratefully thanked for their support during fieldwork. We thank three anonymous reviewers for constructive comments that helped to improve the paper.

\section{Author Contributions}

Pattelli, Rimondi, Paolieri, Costagliola, Rinaldi, Benvenuti, Chiarantini, Colica, Di Benedetto, Lattanzi: sampling and results interpretation. Paolieri: sample preparation and laboratory analyses.

\section{Conflicts of Interest}

The authors declare no conflicts of interest. 


\section{References}

1. Roberts, D.; Nachtegaal, M.; Sparks, D.L. Speciation of Metals in Soils. In Chemical Processes in Soils; Soil Science Society of America Book Series; Tabatabai, M.A., Sparks, D.L., Eds.; Soil Science Society of America: Madison, WI, USA, 2005; Volume 8, pp. 619-654.

2. Chowdhury, B.A.; Chandra, R.K. Biological and health implications of toxic heavy metal and essential trace element interactions. Prog. Food Nutr. Sci. 1986, 11, 55-113.

3. Hylander, L.D.; Meili, M. 500 years of mercury production: Global annual inventory by region until 2000 and associated emissions. Sci. Total Environ. 2003, 304, 13-27.

4. Cossa, D.; Coquery, M. The Mediterranean Mercury Anomaly, a Geochemical or a Biological Issue. In The Mediterranean Sea; Springer: Berlin, Germany, 2005; pp. 177-208.

5. Baldi, F.; D'Amato, M.L. Mercury pollution in marine sediment cores near cinnabar deposits and a chlor-alkali plant. Sci. Total Environ. 1986, 57, 111-120.

6. Barghigiani, C.; Ristori, T. Preliminary study on mercury uptake by Rosmarinus officinalis L. (Rosemary) in a mining area (Mount Amiata, Italy). Bull. Environ. Contam. Toxicol. 1995, 54, 519-525.

7. Rajar, R.; Cetina, M.; Horvat, M.; Žagar, D. Mass balance of mercury in the Mediterranean Sea. Mar. Chem. 2007, 107, 89-102.

8. Bargagli, R.; Barghigiani, C.; Maserti, B.E. Mercury in vegetation of the Mount Amiata area (Italy). Chemosphere 1986, 15, 1035-1042.

9. Ferrara, R.; Maserti, B.E.; Andersson, M.; Edner, H.; Ragnarson, P.; Svanberg, S.; Hernandez, A. Atmospheric mercury concentrations and fluxes in the Almadén district (Spain). Atmos. Environ. 1998, 32, 3897-3904.

10. Gray, J.E.; Hines, M.E.; Higueras, P.L.; Adatto, I.; Lasorsa, B.K. Mercury speciation and microbial transformations in mine wastes, stream sediments, and surface waters at the Almadén mining district, Spain. Environ. Sci. Technol. 2004, 38, 4285-4292.

11. Kim, C.S.; Bloom, N.S.; Rytuba, J.J.; Brown, G.E., Jr. Mercury speciation by X-ray absorption fine structure spectroscopy and sequential chemical extractions: A comparison of speciation methods. Environ. Sci. Technol. 2003, 37, 5102-5108.

12. Higueras, P.; Oyarzun, R.; Lillo, J.; Sànchez-Hernàndez, J.C.; Molina, J.A.; Eesbrì, J.M.; Lorenzo, S. The Almadén district (Spain): Anatomy of one of the world's largest $\mathrm{Hg}$-contaminated sites. Sci. Total Environ. 2006, 236, 112-124.

13. Gosar, M.; Pirc, S.; Bidovec, M. Mercury in the Idrijca River sediments as a reflection of mining and smelting activities of the Idrija mercury mine. J. Geochem. Explor. 1997, 58, 125-131.

14. Gray, J.E.; Crock, J.G.; Fey, D.L. Environmental geochemistry of abandoned mercury mines in West-Central Nevada, USA. Appl. Geochem. 2002, 17, 1069-1079.

15. Gray, J.E.; Greaves, I.A.; Bustos, D.M.; Krabbenhoft, D.P. Mercury and methylmercury contents in mine-waste calcine, water, and sediment collected from the Palawan Quicksilver Mine, Philippines. Environ. Geol. 2003, 43, 298-307. 
16. Rimondi, V.; Gray, J.E.; Costagliola, P.; Vaselli, O.; Lattanzi, P. Concentration, distribution, and translocation of mercury and methylmercury in mine-waste, sediment, soil, water, and fish collected near the Abbadia San Salvatore mercury mine, Monte Amiata district, Italy. Sci. Total Environ. 2012, 414, 318-327.

17. Gray, J.E.; Theodorakos, P.M.; Bailey, E.A.; Turner, R.R. Distribution, speciation, and transport of mercury in stream-sediment, stream-water, and fish collected near abandoned mercury mines in south-western Alaska, USA. Sci. Total Environ. 2000, 260, 21-33.

18. Hines, M.E.; Horvat, M.; Faganeli, J.; Bonzongo, J.C.; Barkay, T.; Major, E.B.; Scott, K.J.; Bailey, E.A.; Warwick, J.J.; Lyons, W.B. Mercury biogeochemistry in the Idrija River, Slovenia, from above the mine into the Gulf of Trieste. Environ. Res. 2000, 83, 129-139.

19. Qiu, G.; Feng, X.; Wang, S.; Shang, L. Mercury and methylmercury in riparian soil, sediments, mine-waste calcines, and moss from abandoned $\mathrm{Hg}$ mines in east Guizhou province, southwestern China. Appl. Geochem. 2005, 20, 627-638.

20. Covelli, S.; Faganeli, J.; De Vittor, C.; Predonzani, S.; Acquavita, A.; Horvat, M. Benthic fluxes of mercury species in a lagoon environment (Grado Lagoon, Northern Adriatic Sea, Italy.) Appl. Geochem. 2008, 23, 529-546.

21. Moretti, G.P.; Cianficconi, F.; Peroni, E.; Ronca, M. Considerazioni sulle comunità macrobentoniche del sistema fluviale Paglia-Chiani. Boll. Mus. Stor. Nat. Lunigiana 1988, 6-7, 157-161. (In Italian)

22. Di Tria, L.; Grimaldi, S.; Napolitano, F.; Ubertini, L. Rainfall Forecasting Using Limited Area Models and Stochastic Models. In Proceedings of EGS Plinius Conference, Maratea, Italy, 14-16 October 1999; pp. 193-204.

23. Navarro, A. Review of characteristics of mercury speciation and mobility from areas of mercury mining in semi-arid environments. Rev. Environ. Sci. Biotechnol. 2008, 7, 287-306.

24. Schäfer, J.; Blanc, G.; Audry, S.; Cossa, D.; Bossy, C. Mercury in the Lot-Garonne River system (France): Sources, fluxes and anthropogenic component. Appl. Geochem. 2006, 21, 515-527.

25. Gray, J.E.; Rimondi, V.; Costagliola, P.; Vaselli, O.; Lattanzi, P. Long-distance transport of Hg, Sb, and As from a mined area, conversion of $\mathrm{Hg}$ to methyl- $\mathrm{Hg}$, and uptake of $\mathrm{Hg}$ by fish on the Tiber River basin, west-central Italy. Environ. Geochem. Health 2014, 36, 145-157.

26. Costantini, S.; Berni, N.; Pandolfo, C.; Stelluti, M.; Zauri, R.; Ponziani, F.; Governatori Leonardi, F.; Francioni, M.; Formica, A.; Marcellini, D.; Casini, L. Evento Alluvionale 11-14 Novembre 2012; Regione Umbria, Servizio Protezione Civile: Perugia, Italy, 2012. Available online: http://www.cfumbria.it/supporto/download/Rapporti_evento/02\%20Novembre\% 202012/CFDUmbria_RapportoEvento_Nov2012.pdf (accessed on 26 March 2014).

27. Barghigiani, C.; Ristori, T. Mercury levels in agricultural products of Mount Amiata (Tuscany, Italy). Arch. Environ. Contam. Toxicol. 1994, 26, 329-334.

28. Strappa, O. Storia delle miniere di mercurio del Mount Amiata. L'industria Mineraria 1977, 28, 252-259. (In Italian)

29. Ferrara, R.; Maserti, B.E.; Breder, R. Mercury in abiotic and biotic compartments of an area affected by a geochemical anomaly (Mount Amiata, Italy). Water Air Soil Pollut. 1991, 56, 219-233. 
30. Bacci, E.; Gaggi, C.; Lanzillotti, E.; Ferrozzi, S. Studio per l'individuazione dei residui di mercurio in forme mobili e della presenza di altri elementi in tracce di interesse ai fini della predisposizione di un progetto di bonifica dell'area di pertinenza della ex miniera di mercurio di Abbadia San Salvatore (SI) (in Italian); ENI S.p.A.-Divisione AGIP, Mining Italiana S.p.A.: Rome, Italy, 1998.

31. Savoia, U. Qua e là per le contrade minerarie d'Italia—Le miniere cinabrifere italiane. La Miniera Italiana III 1919, 7, 233-248. (In Italian)

32. Falini, F. Notizie preliminari di una campagna di indagini e ricerche per minerali di mercurio nella regione del Mount Amiata (province di Siena e Grosseto). Periodico di Mineralogia 1960, 29, 19-45. (In Italian)

33. Zucchetti, S. Giacimenti minerari: I giacimenti mercuriferi secondari della toscana e l'età della loro metallogenesi. Lincei Rend. Sci. Fis. Mat. Natur. 1964, 42, 658-668. (In Italian)

34. Klemm, D.D.; Neumann, N. Ore-Controlling Factors in the Hg-Sb Province of Southern Tuscany, Italy. In Syngenesis and Epigenesis in the Formation of Mineral Deposits; Springer: Berlin, Germany, 1984; pp. 482-503.

35. Morteani, G.; Ruggieri, G.; Möller, P.; Preinfalk, C. Geothermal mineralized scales in the pipe system of the geothermal Piancastagnaio power plant (Mount Amiata geothermal area): A key to understand the stibnite, cinnabarite and gold mineralization of Tuscany (central Italy). Miner. Depos. 2011, 46, 197-210.

36. Girotti, O.; Mancini, M. Plio-Pleistocene stratigraphy and relations between marine and non-marine successions in the Middle valley of the Tiber River (Latium, Umbria). Il Quaternario 2003, 16, 89-106.

37. Italian Ministry of the Environment. Legislative Decree 152/06, Rules on Environmental Subject; Gazzetta Ufficiale No. 88, Supplemento Ordinario No. 96; Italian Ministry of the Environment: Rome, Italy, 2006.

38. MacDonald, D.D.; Ingersoll, C.G.; Berger, T.A. Development and evaluation of consensus-based sediment quality guidelines for freshwater ecosystems. Arch. Environ. Contam. Toxicol. 2000, 39, 20-31.

39. Žibret, G.; Gosar, M. Calculation of the mercury accumulation in the Idrijca River alluvial plain sediments. Sci. Total Environ. 2006, 368, 291-297.

40. Macklin, M.G.; Benito, G.; Gregory, K.J.; Johnstone, E.; Lewin, J.; Michczyńska, D.J.; Soja, R.; Starkel, L.; Thorndycraft, V.R. Past hydrological events reflected in the Holocene fluvial record of Europe. Catena 2006, 66, 145-154.

41. Rimondi, V.; Costagliola, P.; Gray, J.E.; Lattanzi, P.; Nannucci, M.; Paolieri, M.; Salvadori, A. Mass loads of dissolved and particulate mercury and other trace elements in the Mt. Amiata mining district, Southern Tuscany (Italy). Environ. Sci. Pollut. Res. 2014, doi:10.1007/s11356-013-2476-1.

42. Field, C.B.; Barros V.; Stocker, T.F.; Qin, D.; Dokken, D.J.; Ebi, K.L.; Mastrandrea, M.D.; Mach, K.J.; Plattner, G.-K.; Allen, S.K.; Tignor, M.; Midgley, P.M. Managing the Risks of Extreme Events and Disasters to Advance Climate Change Adaptation; A Special Report of Working Groups I and II of the Intergovernmental Panel on Climate Change (IPCC); Cambridge University Press: Cambridge, UK, 2012; pp. 231-290. 
43. Ciccacci, S.; Galiano, M.; Roma, M.A.; Salvatore, M.C. Morphodynamics and morphological changes of the last 50 years in a badland sample area of Southern Tuscany (Italy). Z. Geomorphol. 2009, 53, 273-297.

44. Springborn, M.; Singer, M.B.; Dunne, T. Sediment-adsorbed total mercury flux through Yolo Bypass, the primary floodway and wetland in the Sacramento Valley, California. Sci. Total Environ. 2011, 412-413, 203-213.

45. Singer, M.B.; Aalto, R.; James, L.A.; Kilham, N.E.; Higson, J.L.; Ghoshal, S. Enduring legacy of a toxic fan via episodic redistribution of California gold mining Proc. Natl. Acad. Sci. USA 2013, 110, 18436-18441.

46. White, D.C.; Kirchner, J.W. Assessing water quality impacts and clean up effectiveness in streams dominated by episodic mercury discharges. Sci. Total Environ. 2000, 260, 1-9.

47. Širca, A.; Horvat, M.; Rajar, R.; Covelli, S.; Žagar, D.; Faganeli, J. Estimation of mercury mass balance in the Gulf of Trieste. Acta Adriat. 1999, 40, 75-85.

48. Horvat, M.; Jereb, V.; Fajon, V.; Logar, M.; Kotnik, J.; Faganeli, J.; Hines, M.E.; Bonzongo, J.C. Mercury distribution in water, sediment and soil in the Idrijca and Soĉahca river systems. Geochem. Explor. Environ. Anal. 2002, 2, 287-296.

49. Potter, L.; Kidd, D.; Standiford, D. Mercury levels in Lake Powell. Bioamplification of mercury in man-made desert reservoir. Environ. Sci. Technol. 1975, 9, 41-46.

50. Kwok, K.W.H.; Batley, G.E.; Wenning, R.J.; Zhu, L.; Vangheluwe, M.; Lee, S. Sediment quality guidelines: Challenges and opportunities for improving sediment management. Environ. Sci. Pollut. Res. 2014, 21, 17-27.

(C) 2014 by the authors; licensee MDPI, Basel, Switzerland. This article is an open access article distributed under the terms and conditions of the Creative Commons Attribution license (http://creativecommons.org/licenses/by/3.0/). 